\title{
The development of the service industry in the modern economy: mechanisms and implications for China
}

\author{
Dazhong Cheng
}

Correspondence:

chengdz@fudan.edu.cn

Department of World Economy and Institute for World Economy, Fudan University, No. 600 Guoquan Road,

Shanghai 200433, China

\begin{abstract}
The present paper attempts to examine three types of mechanisms, including specialized division of labor, innovation, and demand-induced mechanisms that are crucial in the development of the service industry in the modern economy. The underdevelopment of transacted-through-market services in China is mainly caused by problems with these three mechanisms and especially by a lower level of specialized division of labor in the market rather than the fact that China is still at an earlier economic development stage than many of the economies used as comparisons. Government strategy should be prioritized to reduce obstacles and transaction costs that are inhibiting the evolution of specialization and the division of labor required for the development of a diverse and dynamic service sector that will help China optimize its economic structure.
\end{abstract}

Keywords: Service economy; Development mechanisms; Tertiarization; Industrialization; Chinese economy

\section{Introduction}

As evidenced by the economic development history of mankind, evolution from an agricultural to an industrial and finally to a service economy is a natural and inevitable process for a specific country and even for the whole world. The agriculturedominated economic society lasted at least to the mid-eighteenth century and the nineteenth century (of course, this does not hold true for all economies in that the agricultural economy for a few backward countries was maintained even longer). The Industrial Revolution, which originated in the UK in the $1860 \mathrm{~s}$, then repeated in France, Germany, Russia, and other European countries, and further spread to the USA and Japan in the nineteenth century, ushered in a new era of industrialization of the world economy dominated by these countries, in which the traditional agricultural economy was gradually replaced by the new industrial economy. Since the USA became the first country to shift to a 'service economy' in the middle of the twentieth century, other countries and developed countries in particular have now transitioned into service economies (see Figure 1$)^{\mathrm{a}}$. This has initiated the tertiarization process of the world economy.

The story about the progression of the economic society of mankind is both important in reality and interesting in theory. Nevertheless, the most important episode is the

(C) 2013 Cheng; licensee Springer. This is an Open Access article distributed under the terms of the Creative Commons Attribution License (http://creativecommons.org/licenses/by/2.0), which permits unrestricted use, distribution, and reproduction in any medium, provided the original work is properly cited. 


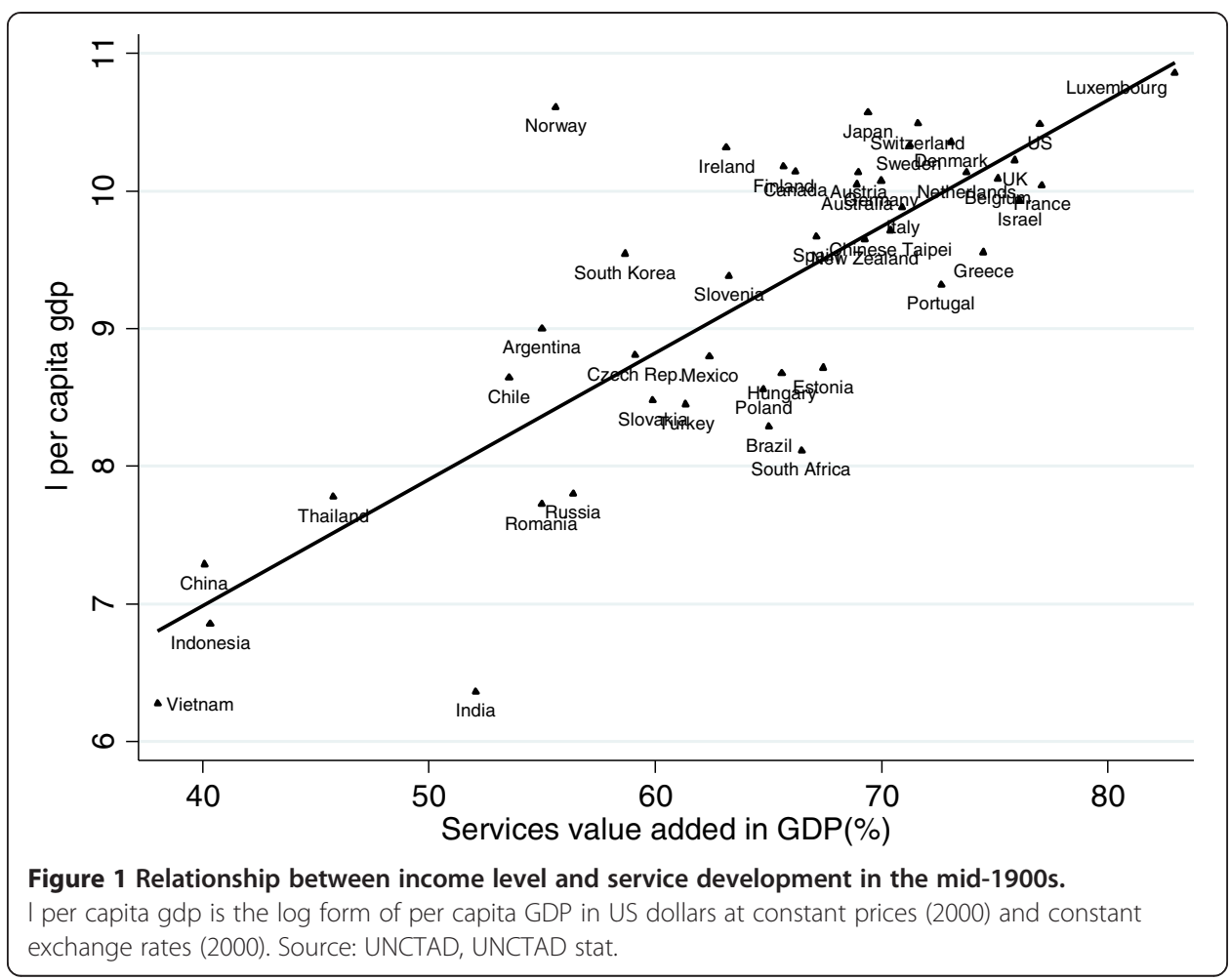

current service economy, which differs from the industrial and agricultural economies in many aspects including output and employment structure, input structure, and international transactions ${ }^{\mathrm{b}}$. This paper attempts to investigate the mechanisms behind the development of the service industry in the modern economy and to highlight strong policy implications for China. More specifically, we focus on three types of mechanisms: specialized division of labor, innovation, and demand-induced mechanisms, which are particularly important for China. China has performed quite differently from other major countries in the evolution of economic society ever since the mid-eighteenth century. The recent rise of China as a major player in the world economy is remarkable. This is not just because it failed to keep pace with the Industrial Revolution but because it has also been disengaged from the twentieth century Service Revolution (see Figure 2). In the new era of the twenty-first century, China is facing great challenges and opportunities both in industrialization and tertiarization. These are no doubt major concerns for researchers as well as policymakers.

\section{Specialized division of labor and service industry development}

The first mechanism driving the development of the service industry is the general trend away from internalization to externalization or, alternatively, from nonmarketization to marketization (see Figure 3). But this evolutionary trend is subject to the trade-off between specialization efficiency and transaction costs (Yang and NG 1993). If specialization efficiency outweighs transaction costs, this evolution will occur and proceed; otherwise, it will stop and even retrogress. In the early stages of economic development, which are characterized by lower levels of marketization and higher 


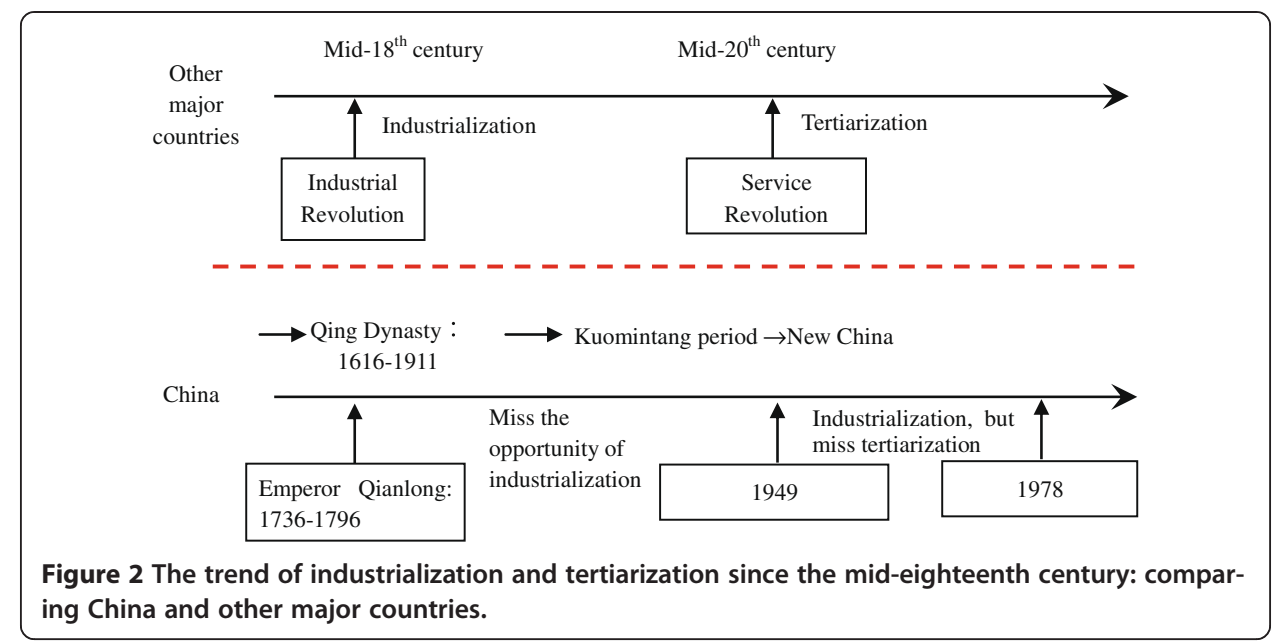

market transaction costs, services are usually supplied in-house by users such as families and firms. As economic development proceeds with increasing marketization and decreasing transaction costs, various independent market agents emerge in the economic system and specialize in the provision of services like accounting, marketing, consulting, logistics, and housekeeping. The demand for services can be satisfied by buying all kinds of services through markets rather than by self-service. This has the effect of increasing the choice of supplier for firms and families that rely primarily on internal provision of services and thus has profound economic implications, although the dichotomy between those provided in-house (i.e., in-house services) and those obtained through market transactions (i.e., transacted-through-market services) is retained.

Let us take producer service as an example (see Figures 3 and 4). The in-house producer services reflect the specialized division of labor inside the producers or firms and, thus, the internal resource allocation and industrial linkages directed by firms' decisions. These types of producer services cannot be captured by input-output tables in the System of National Account (SNA) and will frequently be grouped according to firms' main business (e.g., manufacturing). The transacted-through-market producer services reflect the specialization and division of labor among different firms in the

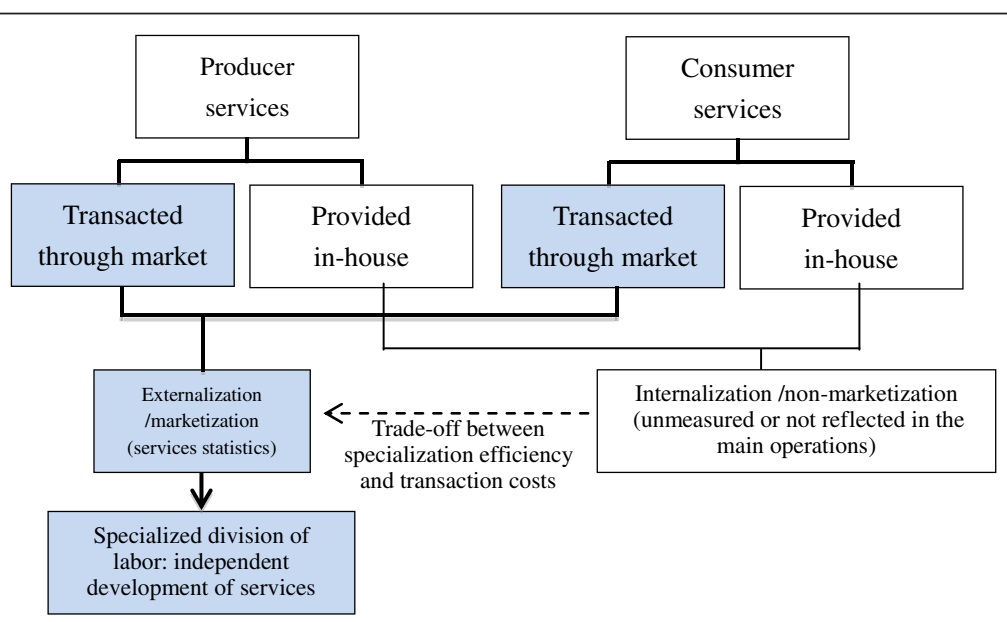

Figure 3 Service industry development: from internalization to externalization. 


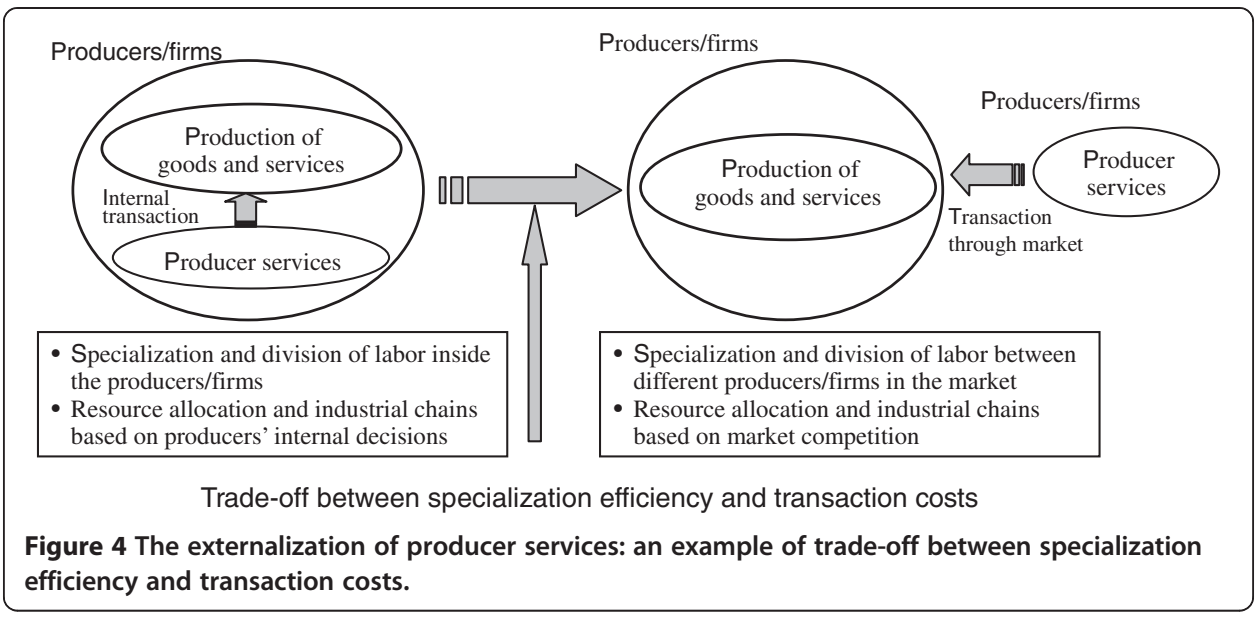

market and, hence, the resource allocation and industrial linkages based on market competition. These types of market-driven producer services will be reported in the SNA input-output tables. The outsourcing and marketization of producer services is a natural evolution of the specialized division of labor and resource allocation from inside the firm to the market. It has the effect of optimizing the value chain and production chain inside the firm, and its core competitiveness will be enhanced. In the meantime, the resource allocation and utilization efficiencies of the firm and of the economy as a whole will be enhanced, the industrial division of labor and structure will become more rational, and the capabilities of the national economy as a whole for innovation and competition will be improved.

The development of services, especially the transacted-through-market services, reflects the extensity (measuring service varieties) and intensity (measuring the specialization level in services) of not only the specialized division of labor in services themselves but also that between services and other industries. Agriculture, manufacturing, and services are all users of producer services, but at the industrialization stage of development, the foremost user is manufacturing. It is generally recognized that the industrialization stage is accompanied by a rapid deepening of the division of labor. At the microeconomic level, the Fordist model of manufacturing production tends to collapse, while the Wintelism induced by the information technology revolution quietly emerges (Borrus and Zysman 1998). Production modes and operational flows begin to change from mass production to customized production and then to mass customization, while the modularization and outsourcing of production sections and operational units gradually increases. These microeconomic changes result in a new industrial division of labor, which, quite different from traditional 'horizontal division of labor' and 'vertical division of labor', is characterized by the 'smiling curve' especially in manufacturing (e.g., information technology (IT) manufacturing). The two ends of the smiling curve, represented by the upstream and the downstream sides of production, are producer services such as research and development (R\&D), sales, and after-sale services for which the value added is higher. The lowest part of the smiling curve, representing the midstream of production, mainly comprises manufacturing, processing, and assembling activities from which the profit is lower. Thus, as production chains extend at both the upstream and downstream sides, profits are gradually shifting 
towards producer services. By incorporating them, manufacturing is gradually being tertiarized while some services become mechanized and automated. Thus, the two kinds of industries become more integrated and interactive. ${ }^{\mathrm{c}}$ In the process of upgrading the product value added by manufacturing, tertiarization develops and accordingly increases and diversifies the demand for services; while in the course of improving the quality of services, more and more hard technologies are introduced for catalyzing technical renovation in manufacturing. This fits the idea of a constantly evolving modern economy in which producer services perform a complementary role that does not involve the replacement of manufacturing or damage to economic growth (Grubel and Walker 1989).

But how do we make the process of specialization and division of labor operate more properly and smoothly? The key lies in reducing transaction costs as much as possible. A full-fledged and congenial market environment and the right policies can be conducive to the reduction in the transaction costs.

\section{The innovation mechanism and service industry development}

During the development process of the service industry itself, there exists a general trend featuring increasing diversification and sophistication of services. The mechanism functioning behind that trend is innovation, which can be identified as two types, with one being technical innovation and the other management innovation. This identification also points to two ways of modernizing traditional services, that is, technical improvement and management improvement. The former implies that a service provider such as a service firm can introduce advanced technologies like information technology and high technology so as to transform its obsolete hardware structure. The latter means that a service provider can reform its old operational and organizational modes by importing modern management expertise and specialized talents. These two types of transformation and improvement can be implemented separately or simultaneously for a specific service provider.

The criteria for identifying a service as traditional or modern lie in whether this service is produced based upon more advanced technologies and/or more advanced management. For example, banking services and retail services are known to be both old and traditional services, but today, they are hugely different from what they were a hundred years ago. On one hand, ITs have been pervasively used in these two service sectors, where, for instance, the service providers tend to operate on the foundation of the Internet. So we can often see and utilize e-banks and e-marts. On the other hand, the providers of these services have also introduced new forms of operation. The supermarket is certainly one of the advanced forms of retail services.

Therefore, if we want to define modern services vis-à-vis traditional services, the best way is to observe whether the providers are operating in the context of more sophisticated technologies and/or newer forms of management. More broadly, modern services should at least cover two groups of services: newly emerging services and modernized traditional services. The former are mainly based on the Internet, including IT informational services, new mobile telecommunication services, etc ${ }^{\mathrm{d}}$., while the latter refers to services which are traditional but have been modernized in terms of the abovementioned two dimensions of advancement. The latter is used even more than the former. 


\section{Demand-induced mechanism and service industry development}

As the preceding discussion of those two mechanisms focuses mainly on the supply side of services, here we turn our attention to the demand side. Undoubtedly, the development of services is the result of equilibrium between demand and supply. Of course, demand includes final demand and intermediate demand. As a rule, the rise in disposable income levels will lead to an increase in final demand for services like health care, entertainment, and tourism ${ }^{\mathrm{e}}$, while the deepening of specialization and industrial divisions will cause a rise in intermediate demand for services like financial, consulting, and accounting services, which we have discussed in the previous section.

As Francois and Hoekman (2010) pointed out, both final and intermediate demand factors are important in explaining the growing share of services in the economy ${ }^{f}$. Early explanations for the rise of services mainly focused on final demand factors (for example, Clark (1940) and Baumol (1967)). Final-demand-side explanations relate the pattern of rising final or consumer service prices and expenditure shares to relative productivity differentials. The result is a prediction of stagnating overall productivity growth, i.e., the so-called Baumol disease, and the related theoretical literature explaining the Balassa-Samuelson effect. Intermediate-demand-side explanations are more recent and emphasize analytical and empirical linkages between intermediate or producer services and the other sectors, assigning both a direct and indirect role for services in the economy and making contrary predictions to those related to the Baumol disease. For instance, Hoekman and Mattoo (2008) stress the conjecture by Francois (1990) that the rising demand for producer services as inputs into manufacturing implies overall productivity growth commensurate with a rising overall service share in employment and value added. This is connected with what Katouzian (1970) called increased roundaboutness of production in general and in manufacturing in particular, i.e., greater specialization and division of labor. Therefore, Francois and Hoekman (2010) argue that an obvious but relatively unexplored avenue for research is a joint analysis of competing final and intermediate demand mechanisms (Baumol 1967; Francois 1990)stagnation linked to consumer services and productivity growth linked to producer services- in a unified framework. Once it is recognized that services are often inputs, an expansion of the service sector can increase growth.

Moreover, we should also consider the nexus of demand and supply. From the supply side, the higher the 'efficiency' is (which can be evaluated by labor productivity and total factor productivity), the better as this is in accord with the objective of service providers' profit maximization. However, from the demand side, the more comfortable the 'effect' is (which can be measured by indices such as customer satisfaction), the better as this fits in with the objective of service consumers' utility maximization. But in reality, the efficiency of suppliers in providing services is often in diametric contradiction to the effect felt by service consumers. One example is the doctor-patient conflict. Suppose you went to see a doctor. You will feel better if the doctor spends more time examining and consulting with great care; otherwise, you will feel bad. If a doctor spends less time for each patient, he will handle more cases, and thus, he performs more efficiently. But this high efficiency would make patients feel very uncomfortable. Hence, the healthy development of the service industry is a balance between efficiency (for the supply side) and effect (for the demand side) rather than putting undue emphasis on the former while ignoring the latter. All the mechanisms and institutional 
and policy designs should take into consideration the interaction between them so as to promote the evolution of services from internalization to externalization.

\section{Policy implications for China}

For a long period after the founding of the People's Republic of China in 1949, service sector development lagged behind, reflecting the fact that the national economic development strategy gave priority to the manufacturing industry, especially the heavy machine industry, as the driver toward immediate industrialization ${ }^{\mathrm{g}}$. The program on reform and opening that China initiated in the late 1970s included significant modifications to economic development doctrines and strategies. These modifications included an increased commitment to clarifying the role of service industries that, albeit gradually, have gained the attention that they deserve. Accelerating the reconfiguration of its industrial structure to include a growing proportion of the service sector in the economy is an essential component in China's new economic development strategy. This is very clearly demonstrated in the numerous references to implementing policies for the development of services in the Eleventh Five-year Plan (2006 to 2010) and in the Twelfth Five-year Plan (2011 to 2015).

There are indications that these service-informed national economic development plans and strategies are taking effect. As the proportion of primary industry value added decreased continuously from $28.2 \%$ to $10.2 \%$ and that of secondary industry value added remained stable at about $47 \%$, the nominal share of services in gross domestic product (GDP) increased from $23.9 \%$ in 1978 to $43 \%$ in 2010. The proportion of service employment in total employment increased from $12.2 \%$ in 1978 to $34.1 \%$ in 2009 , a more rapid rate of change than for the secondary sector (17.3\% to $27.8 \%$ ). The share of primary industry in total employment almost halved from $70.5 \%$ to $38.1 \%$. For every year since 1994, the proportion of service employment in total employment has exceeded the figure for manufacturing with some $80 \%$ of the jobs lost as a result of the reduction in primary industry employment replaced with service rather than manufacturing jobs. Compared with most other countries that are already service economies, the timescale of the shift to services in China has been very short and it also started from a low base. The technological environment is very different from that which accompanied earlier transitions to service economies in Europe or North America, enabling acceleration of a process that previously extended over 50 years and more. But technology such as ICT has also diversified and enhanced the portfolio of information and knowledge-intensive services in developed country service economies, thereby enhancing the quality and competitiveness of their goods-producing and serviceproviding industries. Yet, using the 'Fuchs standard' as the benchmark, even though the expansion of service employment since the early 1990s has been impressive, the case is that at the start of the second decade of the twenty-first century, China is not yet a service economy and cannot even be commensurable with economies such as India and Indonesia that are slightly behind China and others such as Brazil and Russia that are at the same transitional stage as China (see Figure 1 and Table 1).

Why is that? In order to understand these stylized facts about the development of the service industry in China, it is necessary to consider some aspects of the evolution of the economy, especially since the early 1990s. 
Table 1 The adjustment of industrial structure in China: 1952 to 2010

\begin{tabular}{|c|c|c|c|c|c|c|c|}
\hline & Year & $\begin{array}{l}\text { Primary } \\
\text { industry }\end{array}$ & $\begin{array}{c}\text { Secondary } \\
\text { industry }\end{array}$ & Industry & $\begin{array}{l}\text { Tertiary } \\
\text { industry }\end{array}$ & $\begin{array}{l}\text { Transportation, } \\
\text { post, and } \\
\text { telecommunication }\end{array}$ & $\begin{array}{c}\text { Wholesale, } \\
\text { retail, and } \\
\text { catering }\end{array}$ \\
\hline \multirow{7}{*}{$\begin{array}{l}\text { Nominal share } \\
\text { of services in GDP (\%) }\end{array}$} & 1952 & 50.37 & 20.88 & 17.64 & 28.62 & 4.27 & 11.83 \\
\hline & 1978 & 28.19 & 47.88 & 44.09 & 23.94 & 4.99 & 6.65 \\
\hline & 1984 & 32.13 & 43.09 & 38.69 & 24.78 & 4.70 & 5.04 \\
\hline & 1992 & 21.79 & 43.45 & 38.20 & 34.76 & 6.27 & 8.93 \\
\hline & 2001 & 14.39 & 45.15 & 39.74 & 40.46 & 6.27 & 8.32 \\
\hline & 2009 & 10.33 & 46.24 & 39.67 & 43.43 & 4.91 & 8.50 \\
\hline & 2010 & 10.18 & 46.86 & 40.21 & 42.97 & 4.77 & 8.63 \\
\hline \multirow{6}{*}{$\begin{array}{l}\text { Share of services in } \\
\text { total employment (\%) }\end{array}$} & 1952 & 83.54 & 7.39 & & 9.07 & & \\
\hline & 1978 & 70.53 & 17.30 & & 12.18 & & \\
\hline & 1984 & 64.05 & 19.90 & & 16.06 & & \\
\hline & 1992 & 58.50 & 21.70 & & 19.80 & & \\
\hline & 2001 & 50.00 & 22.30 & & 27.70 & & \\
\hline & 2009 & 38.09 & 27.80 & & 34.11 & & \\
\hline
\end{tabular}

Please take note of the following: According to China's statistical classification, the tertiary industry is approximately equivalent to service industry except that the latter also covers services for agriculture, forestry, animal husbandry, and fishing which are included in the primary industry. We will use the terms tertiary industry and service industry interchangeably ${ }^{\mathrm{n}}$. Source: Author's calculation based on the CEIC database.

The early 1990s marked a turning point in the Chinese economy, which had been gradually evolving since the late 1970s when the policy of reform and opening was adopted. ${ }^{\text {h }}$ As the significant changes got underway in the early 1990s, they had the effect of enhancing, or of continuously exacerbating, an already unbalanced situation. First, as reforms of the service sector began to be implemented, with a focus on education, housing, and medical care, the government retained its monopoly of lucrative services such as telecommunication and financial services while discarding the burden of some public services. Most of the latter were used as consumer services, with some of them (e.g., medical services) provided by the private sector but with lower quality and higher prices in the absence of orderly market competition and feasible public management. Consumers have therefore borne more of the burden for educational and medical services. ${ }^{i}$ Second, reforms to the tax system were carried out, giving the central government an increasing share of the total fiscal revenue and thereby enhancing its dominance over the allocation of resources. This has seriously threatened marketization reform and, arguably, has even damaged the market mechanism and competition. Third, the share of government expenditures in the total final expenditure has begun to rise, but this has been accompanied by a decrease in household expenditure as a share of the total. This implies that the government has become bigger and bigger. Fourth, the investment by the central government and its state-owned enterprises (SOEs) and state-owned banks (SOBs) began to increase, including the implementation of numerous ostentatious government office buildings and urban image projects (e.g., Shanghai's magnetic levitation train transport project, which was launched in the early 2000s). Fifth, overproduction of tradable commodities such as apparel and electrical household appliances (due to insufficient domestic demand) coexisted with underproduction of 
non-tradable services and goods (due to monopoly and high prices or costs). This had the effect of causing the merchandise trade surplus to grow and the services trade deficit to persist'. Sixth, a foreign exchange regime reform was introduced so that the renminbi (RMB) devalued significantly against the US dollar in a way that pushed up foreign demand for domestic surplus tradables. Finally, processing trade (i.e., processed and assembled exports using imported materials or intermediates) began to flourish, accounting for almost $50 \%$ of the total trade because of lower labor costs, a relatively weak RMB, and attractive incentives to foreign investors.

The reforms to the service sector and the tax system suggest that the Chinese government has become stronger and stronger in pursuing economic growth, thus intervening in and even replacing the market mechanism, while simultaneously becoming weaker and weaker in the provision of public services ${ }^{k}$. Government officials have an incentive to pursue GDP growth because they can gain promotions and 'benefit' (that is, creating and seeking all kinds of rents). If they do what they should do (i.e., provide public services), the opportunities for 'benefit' are very limited. This has damaged social and business honesty, making market transactions more costly, and has hindered the division of labor and the externalization of producer services. The third and fourth developments since the early 1990s (outlined above) mean that, in effect, government expenditure is squeezing out household expenditure, and government investment policies (via SOEs and SOBs) are discouraging and even forcing out private investment. The emphasis in manufacturing on processing and assembly in China will likely continue, but it will be at the expense of demand for producer services, including upstream services such as $R \& D$ and downstream services such as marketing and after-sale services that are still largely controlled by foreign firms. This unusual processing trade pattern is characterized by two ends abroad and, thus, the coexistence of rapidly developing manufacturing and underdeveloped producer services at home. The overproduction of tradable commodities and the foreign exchange controls are a natural outcome of the distorted government function and behaviors.

Thus, the underdevelopment of market-transacted services remains an integral part of the economic imbalances that are found in the Chinese economy. This is mainly caused by distortions in the level of government involvement and behavior relative to competitor nations rather than the fact that China is still at an earlier stage in the economic development process than many of the economies that have been used for comparison in this study. Institutional and policy distortions have hindered the functions of the three previously discussed mechanisms of service industry development. So the current problems are reflected in three aspects: a lower level of division of labor and specialization due to higher market transaction costs or transaction inefficiency ${ }^{1}$, backward organizational management, and sluggish demand.

As the underdevelopment of market-transacted services is directly due to problems with the three mechanisms and especially due to a lower level of specialized division of labor in services themselves and between services and other industries in the market ${ }^{\mathrm{m}}$, there is a need for the government to remove numerous obstacles (i.e., to reduce transaction costs) to the development of specialization and the division of labor. It is insufficient to rely solely on the introduction of various preferential industrial policies and the designation, for example, of land and buildings as service development zones. The removal of obstacles or the reduction in transaction costs will require a more strategic 
approach, alongside the introduction of policy instruments. The former is more fundamental and profound in that it focuses more on how to transform a country's natural and institutional endowments. Therefore, in the first place, the government needs to standardize its behavior so as to improve the social credibility system and public service functions. It also needs to put the market mechanism in order so that market transactions will become much easier and safer. That is to say, the government should become stronger in offering public services rather than just pursuing GDP growth and intervening in the market. There is also an urgent need to eliminate monopolies in services such as finance, transport, and post and telecommunications, and to promote greater openness to private and foreign investors. This will have the effect of allowing more competition in the provision of services, thereby driving down the price of services as well as helping improve their efficiency, quality, and their integration with the rest of the national economy.

\section{Endnotes}

${ }^{a}$ In his seminal work on The Service Economy, Victor Fuchs (1968) defined a 'service economy' as an economy with more than half of its aggregate employment and output in the service sectors. This is the so-called 'Fuchs standard.'

${ }^{\mathrm{b}}$ Schettkat and Salverda (2004) provide a good summary of the related literature. See also, for instance, Eichengreen and Gupta (2009).

'See also Bryson and Daniels (2010) on the 'manuservice' economy.

${ }^{\mathrm{d}}$ As is well known, the World Wide Web (www) appeared in 1989, and the first website was put into the cyberspace in 1991. Drastic changes have taken place in the past 20 years, which have had profound influences on all aspects of people's life and work.

'The way the demand for a commodity is affected by household expenditures depends on whether this commodity is a luxury, a necessity, or an inferior commodity. Under the assumption that service-related commodities are a luxury, their budget share will have increased over the last decades. On the income side, inequality may also have an effect. When bottom-end incomes and wages lag behind, high-income households can afford to buy services more cheaply (Schettkat and Salverda 2004).

'Just as there have been numerous attempts to define 'services', there are equally numerous attempts to classify them, reflecting the great heterogeneity hiding behind this general label. It is particularly useful to make a distinction between consumer (or final) services and producer (or intermediate) services. Producer services are intermediate services provided to goods or other service producers. Their definition and demarcation is based on a function-based classification of services that was initially proposed by Greenfield (1966) and further developed by Browning and Singelmann (1975). However, it is sometimes difficult to distinguish between producer services and consumer services; activities such as banking or transport services not only fulfill intermediate demand but also meet the needs of final consumers, even though they may emphasize the provision of services to one group or another (see for example Marshall et al. (1988)).

${ }^{\mathrm{g}}$ As a result, the share of services in GDP dropped from $28.6 \%$ in 1952 to $23.9 \%$ in 1978 , while the share of the secondary industry rose from $20.9 \%$ to $47.9 \%$.

hIn the traditional planned economy before the late 1970s, SOEs and people's communes were in fact isolated 'economic kingdoms', with almost no links to each other. 
Enterprises performed 'social functions' (Qiye Ban Shehui). Almost all kinds of services were internalized by SOEs, and people's communes with very few services transacted through the market. The level of specialization and division of labor in the planned economy was therefore very low. This legacy has had a negative influence on the contemporary development of producer services.

${ }^{\mathrm{i}}$ Cheng and Blanchard (2009) have empirically proven that the foremost cause of the increase in the household service expenditure proportion in China has been the rise in service prices rather than income levels. At the same time, the proportion of services on a real supply or value added basis remains unchanged or just grows a little. Therefore, the rises in service expenditure must have not been based on the rise in real supply but on the service price increases. The facts that the labor productivity growth of the service sector is stagnant, the demand for services is price inelastic, and in the meantime the service price is rising gradually show that the signs of 'cost disease' have appeared in service consumption for China as a whole and for most regions.

jThe growth of the merchandise trade surplus (197.62 billon US dollars in 2009) has always surpassed the service trade deficit (29.4 billion US dollars in 2009) so that the overall trade surplus in the balance of payment continues to grow.

${ }^{\mathrm{k}}$ For example, food safety incidents and scandals are almost ubiquitous in China, and the main reason is the lack of necessary public regulation and management. See for example '2008 Chinese milk scandal' available at http://en.wikipedia.org/wiki/2008_ Chinese_milk_scandal.

IThe official statistics show that the total logistic cost occupied 18\% of China's GDP in 2010, which was almost double that of the USA and European countries (10\%).

${ }^{\mathrm{m}}$ With regard to China's services, we should not confuse transacted-through-market services and firm-level in-house services. The producer services documented by industrial-level input-output tables actually refer to the former rather than the latter (Cheng 2012).

${ }^{\mathrm{n}}$ The history of Chinese industrial development and adjustment since 1978 can be roughly divided into four subperiods (shown in Table 1): (1) The first subperiod is from 1978 (when the Third Plenary Session of the Eleventh Central Committee convened) to October 1984 (when the Third Plenary Session of the Twelfth Central Committee convened), when the rural and agricultural reforms beginning from the introduction of the household contract responsibility system became the major driving force of economic development and have solved the problem of feeding the Chinese people. (2) From October 1984 to June 1992, the reforms of state-owned industrial enterprises in cities centering on adjusting ownership structure and rejuvenating enterprises themselves, and the development of township enterprises, have greatly promoted the growth of light industries. As a result, consumer goods became more and more varied, durable consumer goods became popular, and the situation wherein commodities were in short supply has changed fundamentally. (3) From June 1992 (when the Central Committee of the Communist Party of China and the State Council issued the 'Decision on Speeding up the Development of the Tertiary Industry') to December 2001 (when China joined the WTO), the reforms in services began in full swing. (4) Since China's accession to WTO, more industrial reforms and adjustments have been launched to face both internal and external challenges with China's increasing integration with the rest of the world. The economic situation since the third subperiod is also discussed in the text. 


\section{Competing interests}

The authors declare that he has no competing interests.

\section{Authors' information}

Cheng Dazhong is professor and doctoral supervisor of the Department of World Economy and the Institute for World Economy at Fudan University in Shanghai, China. His current research areas include international trade and investment, and service economy and trade in services (with a focus on the internationalization of heterogeneous firms). He has been a Visiting Professor at the University of Technology, Sydney (UTS), Australia and a Visiting Scholar at the University Paris Dauphine, France. He is the author/editor of several books and articles published in professional $\mathrm{CSSCl}$ and SSCl journals and has been in charge of 12 provincial- and national-level research projects. He has won several honors and awards at and above the provincial or ministerial levels and was selected for the Program for New Century Excellent Talents in Chinese Universities (NCET) in 2009.

\section{Acknowledgements}

This research is funded by the Project of the National Natural Science Foundation of China (no. 70773021 and no. 71272069), the Program for New Century Excellent Talents in Chinese Universities (NCET-2009), the Key Project of the Chinese Ministry of Education (no. 12JJD790003 and no. 2007JJD790127), Shanghai Social Sciences Project (2010BJB019), and the ' 985 ' Project of the State Innovative Institute of Fudan University.

Received: 7 January 2013 Accepted: 8 November 2013

Published: 13 December 2013

\section{References}

Baumol W (1967) Macroeconomics of unbalanced growth: the anatomy of urban crisis. Am Econ Rev 57(3):415-426

Borrus M, Zysman J (1998) Globalization with borders: the rise of Wintelism as the future of industrial competition.

In: Zysman J, Schwartz A (eds) Enlarging Europe: the industrial foundations of a new political reality. Research series no.99. University of California, Berkeley, pp 34-69

Browning H, Singelmann J (1975) The emergence of a service society: demographic and sociological aspects of the sectoral transformation of the labor force in the USA. National Technical Information Service, Springfield

Bryson JR, Daniels PW (2010) Service worlds: the "services duality" and the rise of the "manuservice" economy. In: Maglio PP (ed) Service science: research and innovations in the service economy. Handbook of service science, Springer, Heidelberg

Cheng D (2012) Producer services and the evolution of the Chinese economy. In: Yeh A, Yang F (eds) Producer services in China: economic and urban development, Routledge, London

Cheng D, Blanchard J-M (2009) Is the Chinese economy moving in the direction of tertiarization? China World Econ 17(6):88-105

Clark C (1940) The conditions of economic progress. McMillan, London

Eichengreen B, Gupta P (2009) The two waves of service sector growth. NBER working paper no. 14968. The National Bureau of Economic Research, Cambridge

Francois J (1990) Producer services, scale and the division of labor. Oxf Econ Paper 42(4):715-729

Francois J, Hoekman B (2010) Services trade and policy. J Econ Lit 48(3):642-692

Fuchs V (1968) The service economy. National Bureau of Economic Research, Cambridge

Greenfield H (1966) Manpower and the growth of producer services. Columbia University Press, New York

Grubel H, Walker M (1989) Service industry growth: causes and effects. Fraser Institute, Vancouver

Hoekman B, Mattoo A (2008) Services trade and growth. The World Bank policy research working paper no.4461. World Bank, Washington, DC

Katouzian M (1970) The development of the service sector: a new approach. Oxf Econ Paper 22(3):362-382

Marshall J (1988) Services and uneven development. Oxford University Press, London

Schettkat R, Salverda W (2004) Demand patterns and employment growth: consumption and services in France, Germany, the Netherlands, Spain, the United Kingdom and the United States. DEMPATEM project working paper no. 13. Amsterdam Institute for Advanced Labour Studies, Amsterdam

Yang X, NG YK (1993) Specialization and economic organization: a new classical microeconomic framework. North-Holland, Amsterdam

doi:10.1186/2095-4638-1-3

Cite this article as: Cheng: The development of the service industry in the modern economy: mechanisms and implications for China. China Finance and Economic Review 2013 1:3. 